\title{
居住空間構成法と幼稚園児 \\ ARCHITECTURAL SPACE MONTAGE TECHNIQUE AND KINDERGARTEN CHILDREN
}

\author{
岡崎甚 幸*, 柳 沢和彦**, 難 波 美 絵*** \\ Shigeyuki OKAZAKI, Kazuhiko YANAGISAWA and Mie NANBA
}

\begin{abstract}
Architectural Space Montage Technique was designed by the authors. The subject's mental schema is represented by spatial composition of miniatures on a $60 \mathrm{~cm}$ by $90 \mathrm{~cm}$ white plate. The scale for miniatures, such as furniture, people, trees, flowers and many kinds of standardized walls, is 1 to 50 . In this experiment twenty-four kindergarten children made 40 models of the kindergarten. By analyzing each model and the children, we clarified characteristics of spatial composition and many types of subconscious schema, such as maldistribution, primordial enclosure, a great variety of configurations composed of furniture, complex of rooms integrated with corridor.
\end{abstract}

Keywords: kindergarten children, kindergarten, schema, spatial composition, development, Architectural Space Montage Technique

幼稚園児、幼稚園、図式、空間構成、発達、居住空間構成法

\section{研究の背景と目的}

居住空間構成法 (以下KK法之略す) は筆者らの開発によるもので、 1/50の家具、人形、モテュール化された様々な大きさの壁などを木 ワイトボード上に自由に配置して、具体的な生活空間の模型を被験者

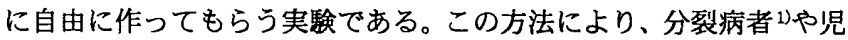
童 2)知的障害児3)の内的世界について報告してきた。

内的世界は、直接目では確認できない。しかしそれは箱庭療法の作 品や描画などを通して外的事物に投影されるものである。河合4,5) は二 ングにもとづいて、箱庭療法の作品を意識と無意識の交錯するところ に存在する一つの心像 image の表現と見る。ピアジエは認識を、「対 象やできごとを変える」操作的側面と「現実の写しのようにみえる」 形象的側面にわけ6)、積極的にいつでも行為となってくりかえされ得 る、行動の下書き、とでもいうべき」7)図式 schèmeを操作的側面に関 わるものとする ${ }^{8}$ 。衛藤9) (風景の組織化と統合のためには、主体内 部に先行的に何らかの内的空間基準が要請される。これは地図のよう な事物の空間配列指示ではなく、それに先立ち、あらゆる事物の空間 配置の可能性を保証し、そのために奥行きと広がりをもった基本的空 間性を目に見えない形で支えている基準である」とし、これを「世界 図式」とよぶ。ここではこれらに基づき、風景の組織化と統合をそれ に先だって支える表象不可能な内的基淮を図式 schema 生1) と呼ぶ。
図式を基準として実際にボード上に具現化された道具の配置を空间 埥成こ呼ぶ。この空間構成から、被験者の潜在的な図式を解明するこ とが本研究の主たる目的である。本論では、幼稚園坚を対象として、 彼らの身近な存在である幼稚園の模型を作ってもらい、その空間構成 から解釈した彼らの図式について報告する。

幼稚園児の図式の解明を目指したのは以下の理由による。まず図式 を求める研究が分裂病者や知的障害児について行われたのは、それら の実験によって、根源的生2)図式が解明されるからである。さらにそ の中でも分裂病者では、寛解過程の患者に比へて急性期の患者におい て、より根源的な図式が得られた。また知的障害児では、教育年限の 短い年少児において、より根源的な図式が現れた。従って、図式が やっと構成されはじめ、それが急速に発達する幼稚園児にも、根源的 な図式が得られる可能性を予測したためである。

これらの図式は、都市や建築空間や庭における繰り返し、内包性、 中心性、対称性等々の基本的な空間の構成をもたらす図式との間の類 似性が高い。また現代病といわれる分裂病者が、その急性期に求める 庇護的空間や、都市や住宅や病院に求められる安らぎの空間との関係 も深い。さらに自閉症や分裂病破瓜型の幾何学的、無機的空間と、分 裂病妄想型の情動的空間との類別は我々の実験結果にもよく見られる ことであるが、これらの背後にある図式は、現代人の空間に対する根
* 京都大学大学院工学研究科 教授.工博

** 京都大学大学院工学研究科 修士課程

*** 㮫環境整備センター 工修
Prof., Graduate School of Engineering, Kyoto Univ., Dr. Eng.

Graduate Student, Graduate School of Engineering, Kyoto Univ.

Environmental Design Center, M. Eng. 
本的な二面性を暗示している。

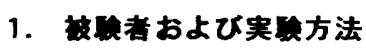

1-1. 教者

三力所の幼稚園で実験を行った。ここでは同 一幼稚園の園児 24 名による、1 年 8 ケ間、延

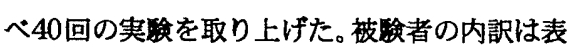
1の通りである。数力月を経て2回目の実験をし たものが12名いる。その中で4名がさらに3回

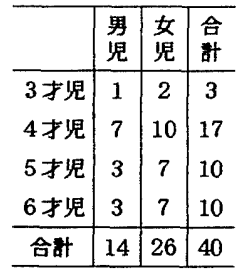

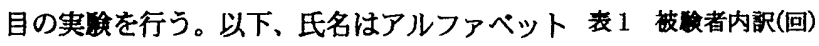
二文字で表示し、複数回制作したものはその後に数字でその回数を表示 する。

\section{1-2. 这其}

児童の実験 ${ }^{2)}$ で用いた道具に、滑り台、砂場のほか、城、汽車という この幼稚園にある遊具の模型を加える。門、犬小屋を欲しがる園児が多 かったため、7回目以降に加える。さらに以下の道具を 24 回目以降に加 える。ウレタン、金網、パンチングメタル、白、青、茶色の透明アクリ ル、半透明アクリル、ミラーで作った同じモデュールの壁。透明ケース に入れた直径的 4〜 $15 \mathrm{~m}$ の砂利、 $50 \mathrm{~cm}$ の鎖 1 本、50 cmの紐 3 本（赤、 黄、言)、 $50 \mathrm{~cm}$ 針金 3 本 (赤、黄、青)。新たに加えたこれらの道具に は特定の意味を与えず、好きなように使ってもらう。

\section{1-3. 实战埧所}

幼稚園は $R C$ 造棟と木造棟と外庭から成り立つ。 $\mathrm{RC}$ 造棟には年中 組、年長組の園児がいる。木造棟には年少組の園児がおり、ここに実 行を行った応接室がある。園児は部屋の北西にある出入り口から入室 し、東に向いて制作する。机の上には大型ホワイトボード $(60 \mathrm{~cm} \times 90$

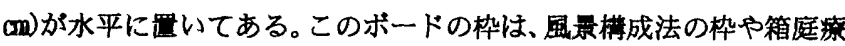
法の箱に相当するものである。その両サイドに小型ホワイトボード (30 cm $\times 45 \mathrm{~cm})$ が二枚ずつ置いてある。小型ホワイトボードの上に各 種の壁が整理して立ててある。その他の道具はボードの左側に立てた 黒い棚 $(\mathrm{H} 90 \mathrm{~cm} \times \mathrm{W} 86 \mathrm{~cm} \times \mathrm{D} 14 \mathrm{~cm})$ に整理して並へてある。園児は木 ワイトボードの前に座り、両サイドにある壁や、棚にある道具を持っ てきて、ホワイトボード上に作品を作っていく。

\section{1-4. 实䗮の手而}

園児が先生に手を引かれて入室する。先生にはそのまま実験に同席 してもらう。実䀫前に「これ何かわかる?」と道具を見せながら訊ね、 答えられないものについては説明する。まず「ここにある道具を好き

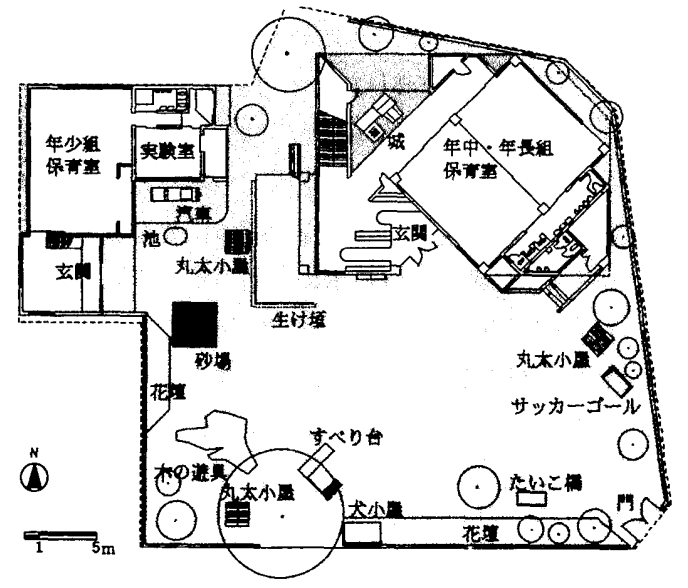

园 1 幼稚国平面図
なだけ使って、このボードの上に幼稚園を作って下さい」と票う。さ らに「人形の中から自分を決めて好きなところに置いて下さい」「完成 したらそう言って下さい。」教示する。制作中に睡かれた家具や壁の 種類、順序、場所を平面図に記録する。発話も全て記録する。制作中 に賈問はしないが、「上手だね」等の励ましは与える。殆どの園児は、 用意してある椅子に座らず立ったままで制作に夢中になる。途中で卜 イレに行くこともある。ボードの奥に回り込んで制作しようとする園 児もいたが、その都度、ボードの手前から作るように指示した。園児 が「できたと言った時点を完成とみなし、その後作品について問 する。同時に幼稚園をどこに何があるかわかるように絵に描いてもら う。この後、最近は風景構成法による描画も試みている。紙面の都合 でこれらの描画とKK法の比較については別䅻にゆずる。

\section{2. 実駼喆果と考寀}

各作品を大まかな発達の順に並べ、そこに見られる幾つかの特徽的 な空間構成を対応させたものが表2である。一つの作品には幾つかの 特徽的な空間構成が互いに重なり合っている。作品の大まかな発達の 順に従った、壁や家具類（遊具、樹木等を含む）、そして人形による 空間構成について考察していく。それと同時に、代表的な作品の考察 も併記する。また、同一被跧者の推移についても考察する。それらに 基づいて 2-4では図式について考察していく。

\section{2-1. 脰や家具䫏による空间槜成}

モテュール化された様々な大きさの壁による空間構成は、ある程度 の抽象的思考操作を支える図式を備えていないと実現できない。し かし具体物、すなわち家具や遊具等は図式が未発達である園児にとっ ても扱いやすい。彼らが棚に置いてある家具や遊具に興味を示すと、 なんとなく置いてみたくなる。しかしそれを手に取ってみた後、ボー ド上のどこに置くべきかということに関しては全くの白紙である。そ のためまず機械的で、均賈で、幾何学的で、制作者の自己中心的な視 点に基づく配置となる。やがて机と椅子の組合せなど、非常に単純な 関係が極小の場に孤立的に発生する。つまりボード上に生活空間が、 構造化された意味のある場として現れはじめる。しかしこの段階では まだ、構造化された意味のある場は、機械的で、均賀で、幾何学的な道 具配置と共存することが多い。やがてその楆小で瓜立的な場は少しずつ 大きくなり、関係も多様になり、他の場との関保付けもできるようにな る。そこで壁や家具類による空間構成の考察に先立ち、家具や遊具の 構成によって、ボード上に構造化された意味のある場があるか否かを判 断することで、諸作品の空間構成を大きく二つに分ける。

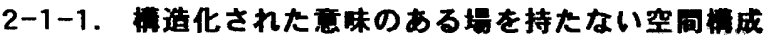

回在(1〜3): 以下、空間構成や氏名記号の後の括弧内は写真番号を 示す。道具をボードの片隅にかためて互いに関係希薄のまま配遇する

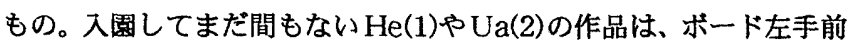
隅に偏在する。

原初的国い $(3,4,9)$ :ボード上に有意味な場が構成されていない段階 でできた壁による囲い。Mk1(3)はボードの右手前隅に円形の曲いを作 り、その中に道具を腺間なく詰め込む。この囲いと、さらに「お椅 子」などといった彼の丁毫な言莱使いは、この子とその母親に対する 祖母の笅しいしつけの現れである。描画でも幼稚園を示す大きな円を 描く。円はスクリブルの次に現れ虫3)、その形が分化するまで、子供 はあらゆるものをこの円によって表現するゅ4。この描画の円と同じよ 
うに、原初的囲いは、のちに外壁、垪として作られる囲いと形こそ似 ているが、その具体的な意味付けはまだされていない未分化なものと 考えられる。 $\mathrm{Ik}(4)$ 紫掴みにした壁を使って大きな囲いを作りな がらその中に遊具を置いていく。この囲いも幼稚園全体を表す原初的 囲いである。その後、砂利を透明ケースごとボード上に撒き散らし た。裹に磁石のついた他の道具と異なり、散乱しやすい砂利の感触か ら砂利遊びに移行し、砂利による崩壊感 ${ }^{10)}$ のため模型を壊してしま う。描画も砂利遊びの影響か、スクリブルである。

正面性保持 $(2,7,8)$ : 人形や道具を全て制作者に対面させて自己中心 的に配置するもの。ここでは 3 例があてはまるが、全ての道具という 条件を除くと、この他に非常に多くの事例で正面向きの道具が見られ る。制作者に対面する道具配置は箱庭療法の作品 ${ }^{10)}$ や知的障害児の 作品 ${ }^{3)}$ でも確認できる。

方向性保持 $(5,6,11 \sim 13,15)$ :ボードの枠の縦と横にきちんと道具 の方向を揃えて配置するもの。正面を向く道具もあるがそうでないも のもある。Mk1(3)は峳しいしつけの現れとして原初的囲いを作った が、9ケ月後のMk2(5)は方向性保持に変わった。これは幼稚園との家 庭面談、その後の母親の育児の軽減、そして彼女のバレーボールチー ムへの参加など、家庭環境の変化による。さらにその7ヶ月後の $\mathrm{Mk} 3$

\begin{tabular}{|c|c|c|c|c|c|c|c|c|c|c|c|c|c|c|c|c|c|c|c|}
\hline \multirow{4}{*}{\multicolumn{2}{|c|}{ 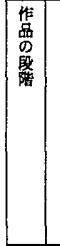 }} & \multirow{4}{*}{\multicolumn{2}{|c|}{ 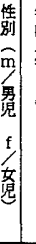 }} & \multirow{4}{*}{\multicolumn{2}{|c|}{ 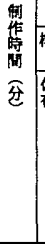 }} & \multicolumn{12}{|c|}{ 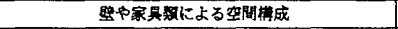 } & \multicolumn{2}{|c|}{ 人形による空的棰成 } \\
\hline & \multirow{3}{*}{ 唇 } & & \multirow{3}{*}{\multicolumn{2}{|c|}{$\begin{array}{l}\text { 年 } \\
\text { 湆 } \\
\text { 年 } \\
\text { 盲 }\end{array}$}} & & \multicolumn{4}{|c|}{ 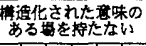 } & \multicolumn{8}{|c|}{ 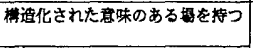 } & \multirow{3}{*}{ 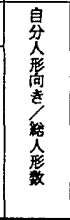 } & \multirow{3}{*}{ 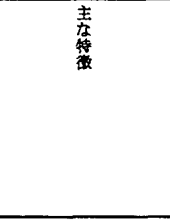 } \\
\hline & & & & & & & & & & 䝷 & & & & 漂成 & & & 曻 & & \\
\hline & & & & & & & & & & 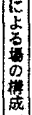 & 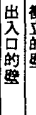 & & & & & & 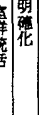 & & \\
\hline \multirow{9}{*}{ 原 } & $\mathrm{He}$ & $f$ & 4.0 & 12 & $*$ & & & & & & & & & & & & & 10 & \\
\hline & $\mathrm{Ua}$ & $f$ & 4.2 & 4 & $*$ & * & $*$ & & & & & & & & & & & 12 & \\
\hline & MKE I & m & 4.0 & 17 & & $*$ & & & & & & & & & & & & $\rightarrow / 1$ & \\
\hline & $\mathrm{Kk}$ & $m$ & 3.2 & 31 & & $*$ & & & & & & & & & & & & 10 & \\
\hline & Mk2 & $\mathrm{m}$ & 4.9 & 39 & & & & $*$ & $*$ & & & & & & & & & $+/ 1$ & \\
\hline & Mk3 & $\mathrm{m}$ & 5.4. & 26 & & & & * & & & & & & & & & & 10 & \\
\hline & $\mathrm{Mm} 1$ & $f$ & 4.6 & 17 & & & $*$ & & * * * & & & & & & & & & 10 & \\
\hline & $\mathrm{Mm} 2$ & 1 & 4.6 & 20 & & & $*$ & & * & & & & & & & & & $1 / 2$ & 列犾 \\
\hline & $\mathrm{Dm}$ & $f$ & 4.5 & 17 & & $*$ & & & . & & & & & & & & & 14 & 列状 \\
\hline \multirow{8}{*}{ 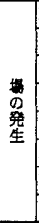 } & Ms1 & $\mathrm{m}$ & 4.0 & 71 & & & & & $*$ & $\Delta$ & * & & & & & & & $\uparrow / 14$ & 卜イレ前列，分散 \\
\hline & UkI & $f$ & 3.1 & 70 & & & & $*$ & 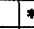 & $\Delta$ & $* 1$ & *1* & . & & & & & $1 / 27$ & 列状 \\
\hline & Ks1 & $\mathrm{f}$ & 3.1 & 35 & & & & $*$ & * & $\Delta$ & * & $*$ & . & & & & & $\uparrow / 18$ & \\
\hline & $\mathrm{KhI}$ & $\mathrm{m}$ & 4.6 & 29 & & & & * & * & $\Delta$ & * & & & & & & & $\leftarrow / 9$ & \\
\hline & Uk2 & $f$ & 4.6 & 23 & & & & & 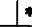 & $\Delta$ & & 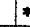 & 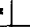 & & & & & $\pi / 26$ & 群 \\
\hline & $\operatorname{Min} 3$ & $f$ & 5.8 & 42 & & & & * & $\pi$ & $\Delta$ & $* 1$ & * & & & & & & $+/ 11$ & 列状 \\
\hline & Us & $\mathrm{m}$ & 4.3 & 25 & & & & & $*$ & $\Delta$ & $*$ & $*$ & . & & & & & $\rightarrow / 24$ & 分敬 \\
\hline & Ks2 & $\mathrm{f}$ & 4.5 & 42 & & & & & & $\Delta$ & $*$ & $* 7$ & ] & & & & & $1 / 23$ & 聞の槽に母子样 \\
\hline \multirow{19}{*}{ 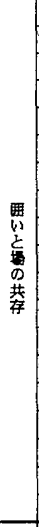 } & Kh2 & $m$ & 4.1 & 34 & & & & & & o & D: & * & $*$ & & & & & \begin{tabular}{|l|l|}
$\pi / 9$ \\
\end{tabular} & \\
\hline & $\mathrm{Te1}$ & $f$ & 4.8 & 10 & & & & & & o & & & * & & & & & $1 / 25 *$ & 囲い每に多数配植 \\
\hline & Ms2 & $\underline{m}$ & 5.1. & 76 & & & & & & 0 & * & ** & $*$ & $*$ & & & & $1 / 7$ & \\
\hline & IrI & $f$ & 4.5 & 30 & & & & & & O & & $*$ & $*$ & & & & * & $1 / 1$ & \\
\hline & K\$3 & $\mathrm{f}$ & 5. & 49 & & & & & & O & & $*$ & * & & $\mathbf{\Delta}$ & & $*$ & $1 / 16$ & 有子とともに列 \\
\hline & $\mathrm{Hk}$ & $\mathrm{m}$ & 6.1. & 28 & & & & & & 0 & & & $*$ & & $\Delta$ & & * & -13 & \\
\hline & $\mathrm{Hm}$ & $t$ & 6.5 & 99 & & & & & & 0 & & *. & & & $\Delta$ & & $*$ & $\uparrow / 26$ & \\
\hline & Yt1 & $\mathrm{f}$ & 4.1 & 50 & & & & & & 2 & & & $*$ & $*$ & & & $*$ & $1 / 3$ & \\
\hline & $\mathrm{Ym}$ & $\mathrm{m}$ & 6. & 77 & & & & & & (1) & & & $*$ & & $\Delta$ & & $*$ & $\uparrow / 1$ & \\
\hline & $\mathrm{Yk}_{\mathrm{k}}$ & $f$ & 6. & 11 & & & & & & 0 & & & $*$ & & & & $*$ & $\leftarrow / 17$ & になって歪が \\
\hline & Or1 & $f$ & 5. & 18 & & & & & & (2) & & & & & $*$ & & $*$ & $1 / 5$ & \\
\hline & Ty1 & $f$ & 5. & 52 & & & & & & (2) & & & & $*$ & & & $*$ & $1 / 4$ & \\
\hline & $\mathrm{Tm}$ & $\mathrm{m}$ & 4.1 & 65 & & & & & & 10 & & + & . & & $*$ & * & * & -115 & \\
\hline & Te3 & $\mathrm{f}$ & 5.1 & 54 & & & & & & 0 & 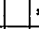 & $*$ & * & $*$ & $\mathbf{\Delta}$ & * & * & $\rightarrow / 27$ & \\
\hline & Ih1 & $\mathrm{f}$ & 5.1 & 92 & & & & & & (2) & & & & $*$ & & * & $*$ & $\uparrow / 7$ & \\
\hline & Yt2 & $\mathrm{f}$ & 6. & 53 & & & & & & 0 & & & & & & * & $*$ & $\leftarrow / 13$ & \\
\hline & Ir2 & $f$ & 6. & 22 & & & & & & (2) & & & & & & * & $*$ & $\rightarrow / 3$ & \\
\hline & Or2 & $\mathrm{f}$ & 6. & 47 & & & & & & 10 & & & & * & A & * & $*$ & $\sqrt{ } / 22$ & 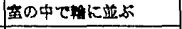 \\
\hline & $\mathrm{Te} 2$ & $\underline{f}$ & 5. & 11 & & & & & & 10 & & & & $*$ & & * & $*$ & $\downarrow / 6$ & \\
\hline \multirow{4}{*}{ 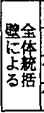 } & Kt & $\mathrm{m}$ & 6. & 35 & & & & & & 0 & & & $*$ & & & & $* *$ & $\leftarrow / 1$ & \\
\hline & Ih2 & $\mathrm{f}$ & 6. & 64 & & & & & & 10 & & & & * & $*$ & $*$ & $\begin{array}{ll}* \\
*\end{array}$ & $※ / 24 *$ & 1日日生活の時仙的麦現 \\
\hline & Ts & $\mathrm{m}$ & 5. & 29 & & & & & & 0 & & & & & $*$ & & * & $\uparrow / 28$ & 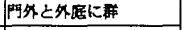 \\
\hline & Ty2 & $\mathrm{f}$ & 6. & 79 & & & & & & 10 & & & & & 4 & & *1* & $1 / 25$ & 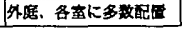 \\
\hline
\end{tabular}

(6)の作品もMk2 と殆ど変わりがなく、全体の印象は希薄である。Ks1 (12)、Kh1(13)のようにボードの方向性を保持しているが、部分的に 人形や家具類の組合せによる場が見られるものもある。Uk2(14)のよ うに、作りはじめでは方向性保持であるが、人形群を別の向きに置い てから方向が統一されなくなった例もある。

一様分布 $(5,7,8,12,13)$ :道具を互いに関保希薄のままボード全域に ほぼ均等に配置するもの。一様分布は、作業領域が偏った範囲から全 域に㹡がった状態と見ることができる。

列状 $(7 \sim 11,14 \sim 16)$ : 同種の道具を幾つも並べていくもの。 $\mathrm{Mm1}(7)$ は実験直前の午前中におもらしをしてしまい、母親に内緒で先生に下着 を乾かしてもらう。このような不安定な気持ちで作られた作品は壁が一 様に分布し、全ての壁面が自分の方を向く列状となる。 $\mathrm{Mm} 2(8)$ のKK法 はMm1の描画の直後に作られたものである。描画の出来が比較的良かっ たため再度作ってもらった作品である。 $\mathrm{Mm} 1$ とは対照的に壁を全く使わ ないが、一様分布、正面性保持、列状といった構成は変わらない。Uk1 (11)のように熱心に、楽しそうに列状を構成するものもある。Uk1 はまず、自分に対面させながら子ども人形の列と大人人形の列を作 る。同様にテーブルも列状に並べていく。さらにテーブルのそれぞれ に対して、椅子を一つずつ置いていく。机と椅子の列は 7 カ後の Uk2(14)も作るが、Uk1 では正面向きであったのにUk2 ではボード の左側を向いて一列縦隊をなす。さらにUk1では正面を向いて列を 成していた人形が、Uk2ではあらゆる方向を向いて群をなす。自己中 心的な構成から、対象中心的な構成への移行が見て取れる。

\section{2-1-2. 檽造化された意味のある場を持つ空同棈成}

家具類による場の棈成(10４0):日常生活で関係がある家具類を 組み合わせて、意味のある場を作るもの。これは対象中心的な構成が できることを示している。Uk1(11)に見る机と椅子のようにごく僅か な家具の組合せから、 $\mathrm{Hm}(24)$ のように家具や遊具等の具体物だけで 作品全体を構成するものまで、様々な段階が見られる。Hmは壁を一 枚も使わない。壁を使って空間を構造化するかわりに、家具類を連接 させ、またそれらを衝立的に用いることなどで複雑な棈成をする。

出入口的毠(10〜13,15 17,20): 単独の壁を、その中に開けられ た出入口として使うもの。家具と同じような具体物として扱われる。

雷立的壁 $(11,15 \sim 18,20,24,31)$ : 単独の壁で、家具類の背景として 置くものや、家具類による二つの場を仕切るようにその間に置くもの。

速接的壁 $(11,12,14,16,17,20 \sim 22,24,30,31)$ : 複数の壁を場の意味に 基づいて一直線状に並べるもの。その殆どが外壁や垪の萌芽と考えられ るが、単に同種のものを組み合わせていく列状配置と区別がつかないも のもある。Us(16)やIr1(21)はボード手前側に二列の連接的壁を作り、そ

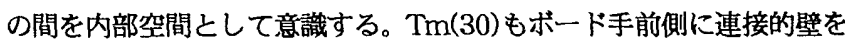
構成する。このようにボード手前側に構成する連接的壁は、作品の世界 を制作者の世界から区別する境界のような働きをすると思われる。

不完全国い(18～23,25 27,37): 室や幼稚園等を示す囲いで、四 辺のいずれかに壁がないか、あっても閉じていないもの。囲い間のつ ながりを意識させるものもある。Kh2(18)は便器や洗面台でコの字型 を作り、その左側には机と椅子による場を構成する。この二つの場を 仕切るようにその間に壁を置き、机之椅子の場は壁による不完全囲い、 トイレは具体物を中心とした不完全囲いとなる。Te1(19)はこのような 小さな道具で遊ぶのが大好きとのことである。ボード右側にできた幼 稚園は、三辺を壁で囲い残りの一辺をホワイトボードの縁で代用した 


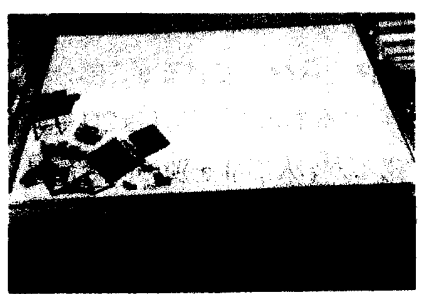

军真 1 He(f4.0) 荱在

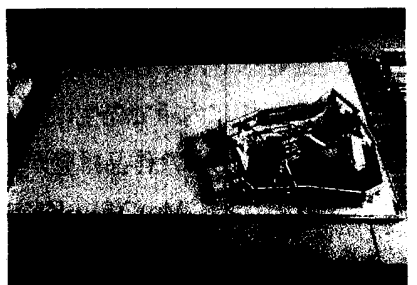

写真 $3 \mathrm{Mk} 1(\mathrm{~m} 4.0)$ 㣂在、原初的囲い

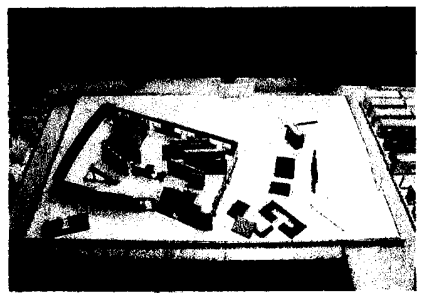

军真 $4 \mathrm{Ik}(\mathrm{m} 3.7)$ 原初的囲い

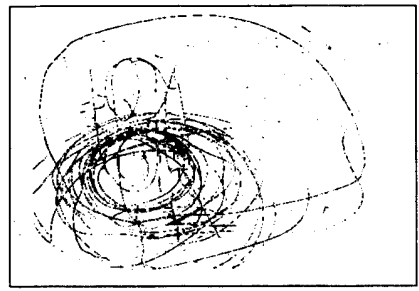

図4 描画 $\mathrm{Ik}$ スクリブル

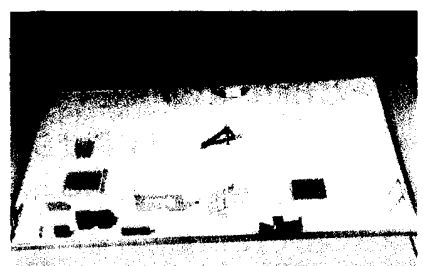

军真 $5 \mathrm{Mk} 2(\mathrm{~m} 4.9)$ 方向性保持など

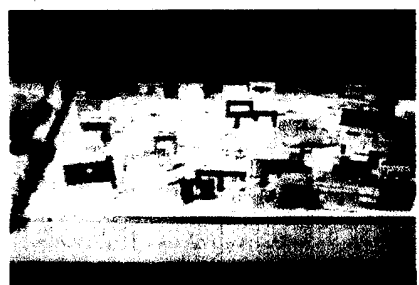

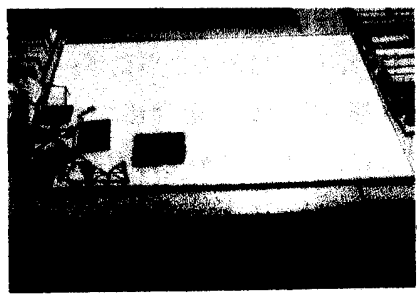

写真 $2 \mathrm{Ua}$ (f4.2) 侕在、正面性保持

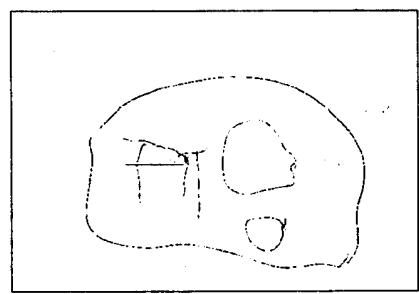

図 2 描画 Mk1 円

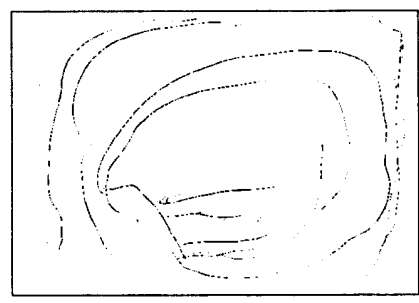

図 3 描画 $\mathrm{Ik}$ スクリブル

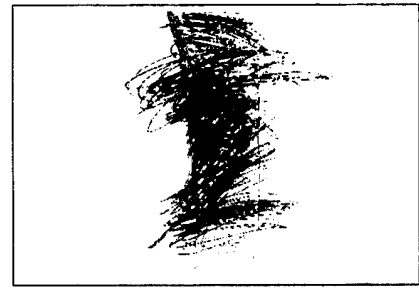

図5 描画 $\mathrm{k}$ ぬつふぶし

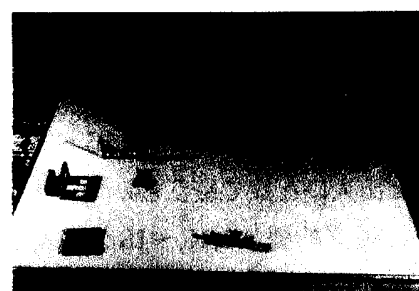

写真6 Mk3(m5.4) 方向性保持。

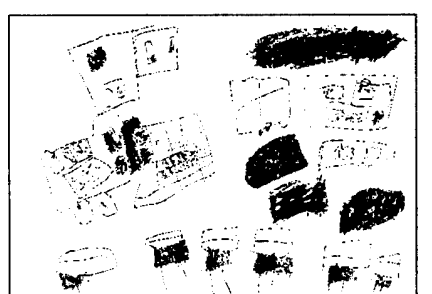

军真 $7 \mathrm{Mml}$ (f4.6) 一様分布、列状など图 6 描画 $\mathrm{Mm} 1$ ならべ描きなど

不完全囲いとなる。囲いの一辺をホワイトボードの縁で代用すること は览童の作品2でも見られる。さらにいくつかの不完全に囲われた場 が互いに瓜立した状態で作られ、それぞれに「わたしのおうち」学校」 などの役割が与えられる。不完全囲いはKh2やTe1のように末熟なも のから、Yk(27)のようにしっかりとした構成のものまである。

完全国い $(20,25,29,31,32,35,36,38)$ :室や幼稚園等を示す囲いで、 単独に存在し、しっかりと閉じているもの。Yt1(25)の作品には、完
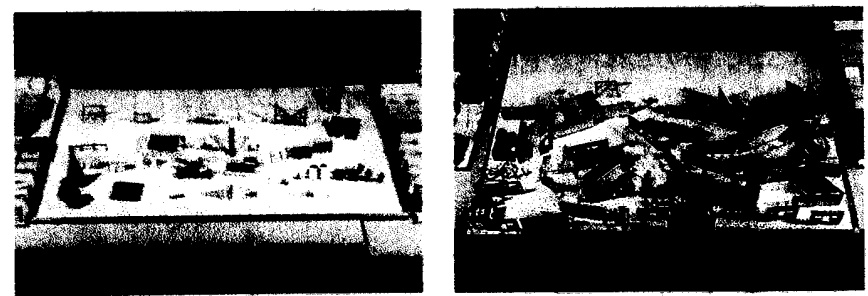

写真 $8 \mathrm{Mm} 2(\mathrm{f} 4.6)$ 一様分布、列状など 写真 $9 \mathrm{Dm}$ (f4.3) 列状など
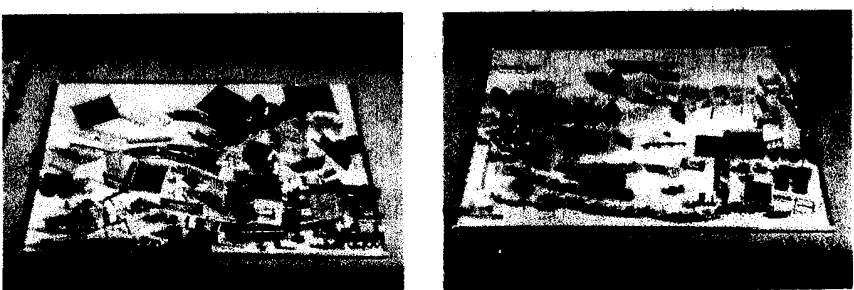

写真10 Ms1(m4.0) 列状、家鱼堨など 写真 $11 \mathrm{Ukl}$ (f3.11) 列状、家具場など

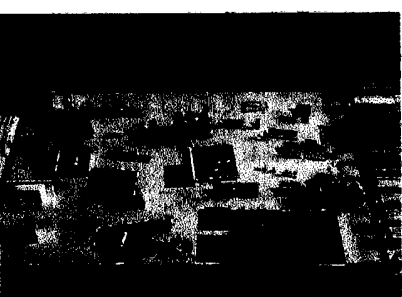

写真 $12 \mathrm{Ks} 1$ (f3.11) 一様分布など
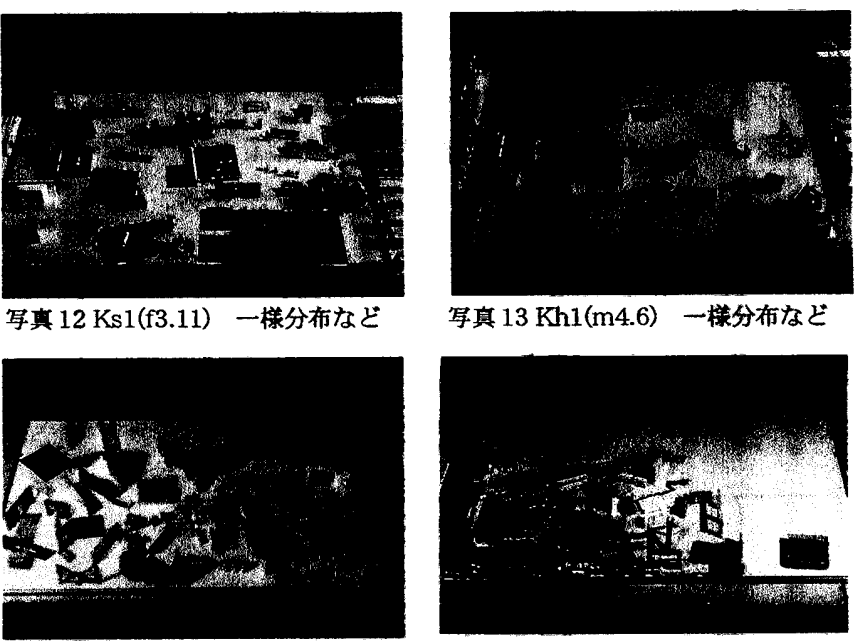

写真 $14 \mathrm{Uk} 2(\mathrm{f} 4.6)$ 列状、家具場など
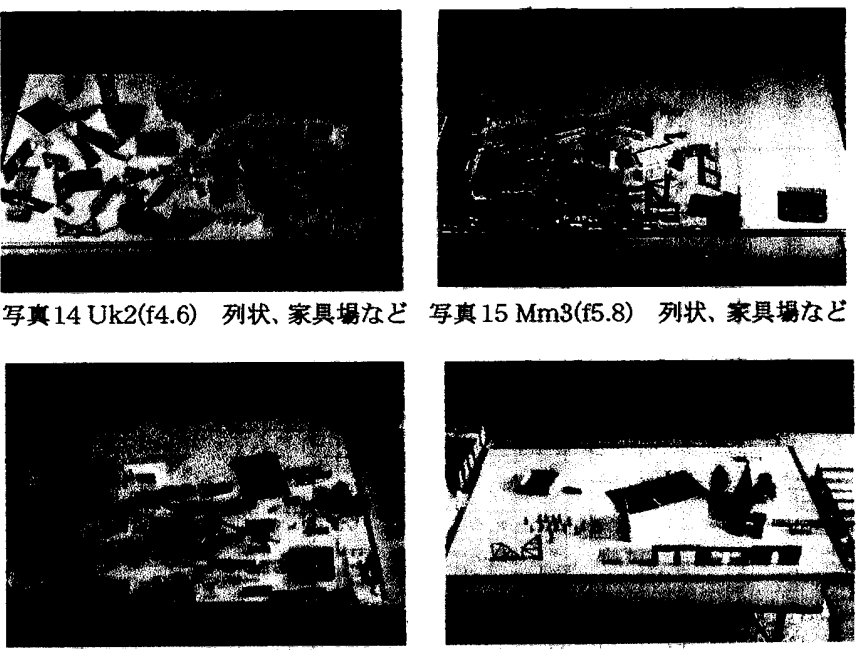

写真 $16 \mathrm{Us}(\mathrm{m} 4.3)$ 列状、家奥場など 写真 $17 \mathrm{Ks} 2(\mathrm{f} 4.3)$ 家具埸、连接暨など
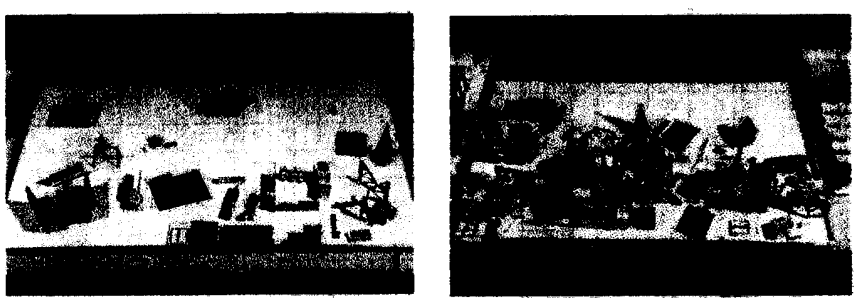

写真 $18 \mathrm{Kh} 2(\mathrm{~m} 4.11)$ 不完全囲いなど 写真19 Te1(f4.8) 不完全用いなど

全囲いをはじめとして様々な壁の使用が見られる。ボード右奥の年中 組と年長組は、幾つかの家具類による場がまとまりをなす不完全囲い である。その手前の外部トイレも、トイレブースが壁の代わりに囲い の数辺を構成する不完全囲いとなる。対照的にボード左側の年少組は 壁をきちんと接合した完全囲いで作られる。Ty1(29)は内部に、家具 類による場を複数含む完全囲いで幼稚園を楧成する。その内部は壁で 区切られることはなく、場と場の関保は瞹昧である。 


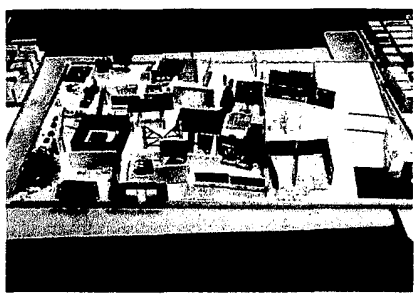

写真 $20 \mathrm{Ms} 2(\mathrm{~m} 5.1$ ） 不完全囲いなど

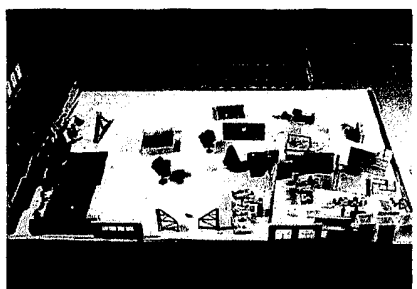

写真 $22 \mathrm{Ks} 3(\mathrm{f} 5.3)$ 不完全囲いなど

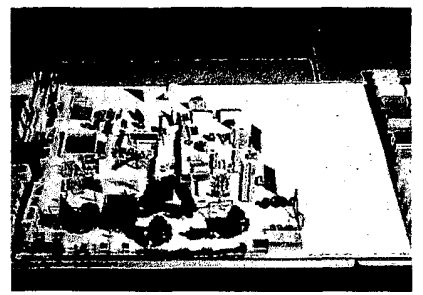

写真 $24 \mathrm{Hm}$ (f6.5) 家具場など

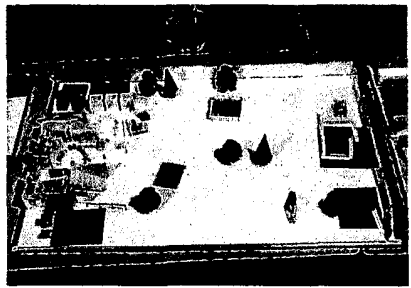

写真 $26 \mathrm{Ym}(\mathrm{m} 6.5)$ 不完全囲いなど

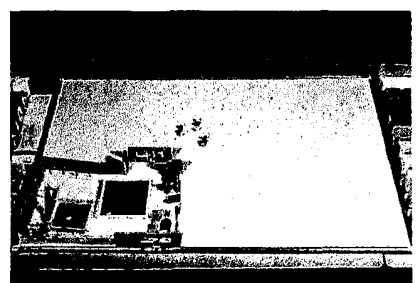

写真28 Or1(f5.5) 包括的囲いなど

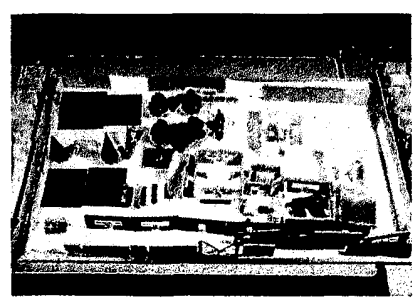

写真30 $\mathrm{Tm}(\mathrm{m} 4.11)$ 完全囲い群など

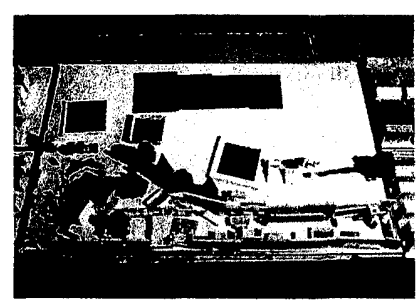

写真21 Ir1(f4.9) 不完全囲いなど

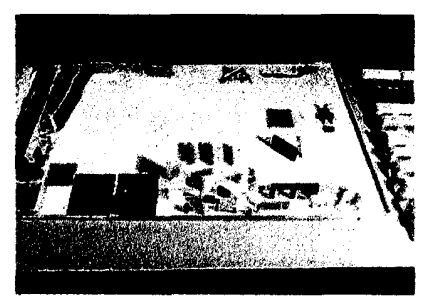

写真 $23 \mathrm{Hk}(\mathrm{m} 6.1)$ 不完全囲いなど

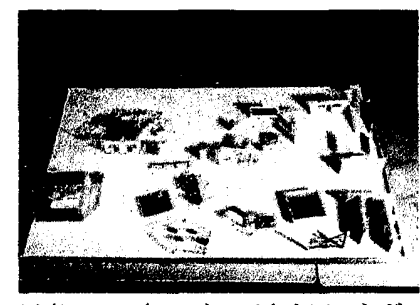

写真25 Yt1(f4.11）不完全囲いなど

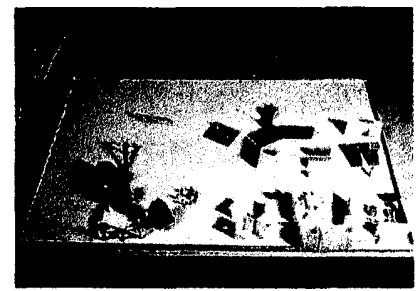

写真 $27 \mathrm{Yk}(\mathrm{f} 6.7)$ 不完全囲いなど

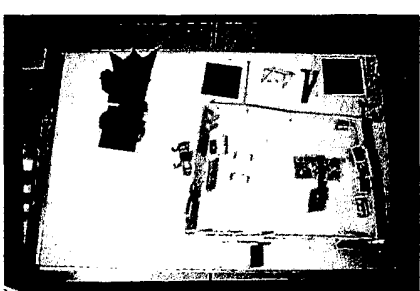

写真 29 Ty1(f5.8) 完全囲いなど

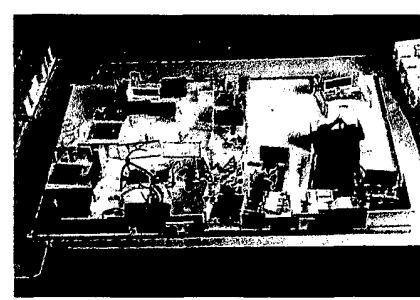

写真31 Te3(f5.11) 包括的囲いなど

包括的国い $(22 \sim 24,26,28,30,31,35,38,39)$ : 家具類による場を内 部に複数含み、広い範囲を統括し、外庭の周りの塀を意味すると考えら れる囲い。不完全な囲いと完全な囲いがある。Ym(26)はボードの枠 に沿って、L字型に包括的囲いを構成する。Or1(28)も包括的囲いを構 成する。この囲い内部は、まるで図と地が反転したように外庭を意味す る。Ih2(38)やTs(39)では、包括的囲いはもはや、完全に閉じた明確な 荆として構成されるようになる。

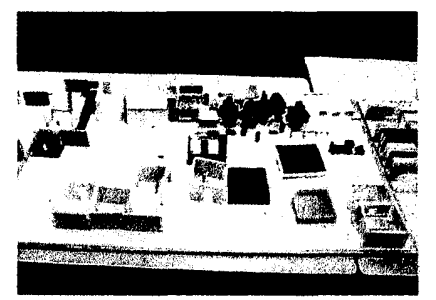

写真 $32 \operatorname{Ih} 1(f 5.10)$ 完全囲い群など

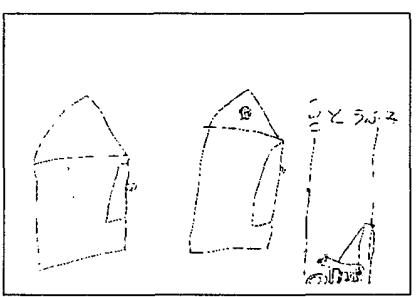

図 8 描画 Ih1 家の典型的様式

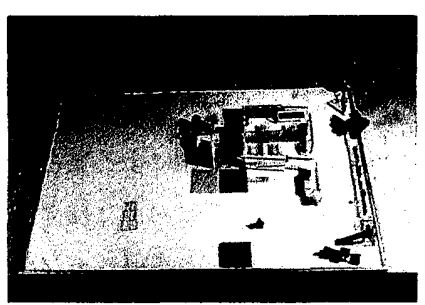

写真 34 Ir2(f6.2) 完全团い群など

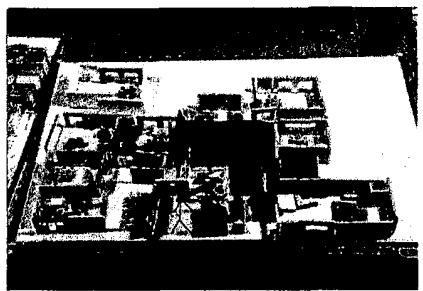

写真 $36 \mathrm{Te} 2(\mathrm{f} 5.3)$ 完全囲い群など

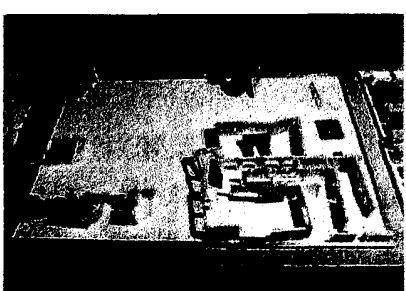

写真 $37 \mathrm{Kt}(\mathrm{m} 6.3)$ 室群統括など

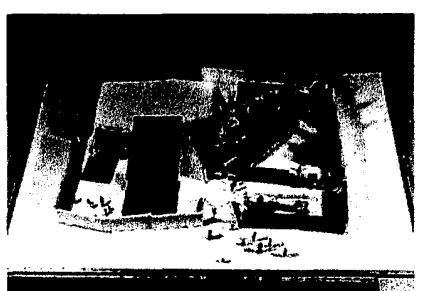

写真 $39 \mathrm{Ts}(\mathrm{m} 5.3)$ 室群統括など

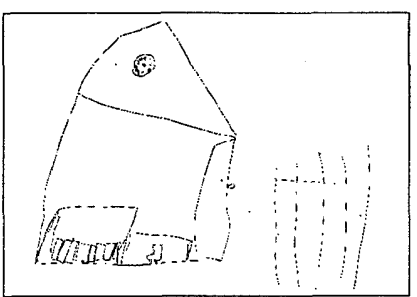

図 7 描画 $\ln 1$ 家の典型的梯式

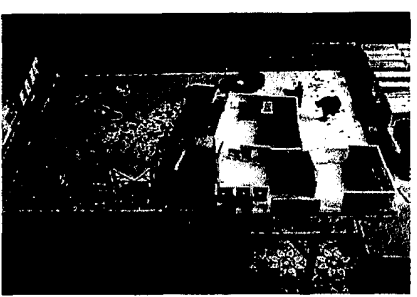

写真 33 Yt2(f6.2) 完全团い群など

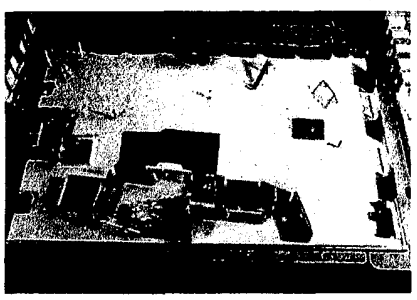

写真35 Or2(f6.9) 完全囲い群など

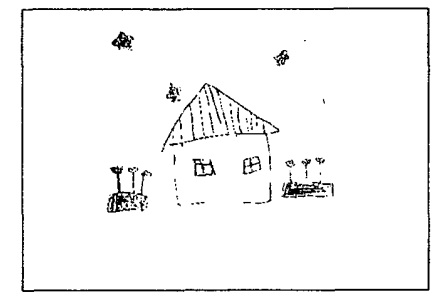

図 9 描画 $\mathrm{Te} 2$ 家の典型的様式

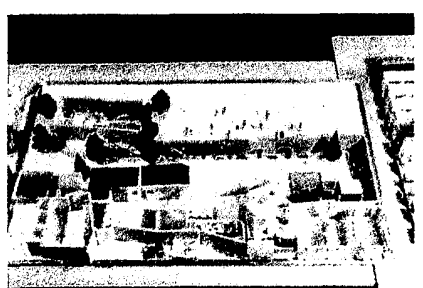

写真 38 Ih2(f6.2) 室群統括など

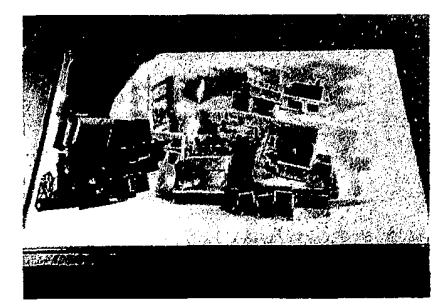

写真 40 Ty2(f6.2） 室群統括など

完全国い群(30〜36,38): 複数の完全囲いが増殖や分割によってひ とまとまりをなすもの。囲い間のつながりを意識させる。Ih1(32)は内 部に家具が殆ど置かれない完全囲い群を構成する。描画では三角屋根 にドアのある四角の壁を組み合わせた家の典型的様式を反復して描く。 $\mathrm{Te} 2(36)$ は同じような家具の組み合わせを持つ反復的な完全囲い群を 構成する。描画はIh1 と同様、家の典型的様式である。壁による完全 な囲いは、子どもの描画によく見られる家の典型的様式のように、幼 
稚園を示す記号的なものである。

室群楛括 (37〜 40): はっきりそれとわかる廊下と空、そしてそれ らのつながりを壁で明確に構成し、全体を統括するもの。ピアジェの いうユークリッド的な関係も幾らか配感され、保育室を広く、トイレ を狭く、廊下を細長くというような区別が見られる。また、実際の幼 稚園は玄関と廊下が 45 度振れているが、Ts(39)はこのような角度の 振れを表現する。Ty2(40)の作品は最も完成度が高いものである。彼 女はまず、壁のみで廊下、玄関、保育室を明碓に示していく。その後 内部に家具や人形を贯き、生き生きとした生活空間を構成する。

2-1-1 と2-1-2 のまとめ

然間槽成の考察により、作品群は原初的、場の発生、囲いと場の共 存、壁による全体統括の四つの段階に大別することができる。原初的 段階とは、偏在、原初的囲い、正面性保持、方向性保持、一様分布、列 状といった空間满成が見られるが、まだ家具類による場の構成はあら われていないものである。埼の発生の段階とは、原初的段階の空間構 成が依然として見られるが、部分的に家具類による場が構成されるよ うになるもので、それと同時に出入口的壁、街立的壁、連接的壁も見 られるようになる。国いと場の共存の段階とは、家具類による場とと もに不完全囲い、完全囲い、包括的囲い、完全囲い群といった様々な 囲いが見られるものである。垃による全体蓅括の段階とは、より离 度な家具類による場とともに、壁で明確に廊下や玄関、そして室を意 味付けして作品全体を統括する空群統括が見られるものである。

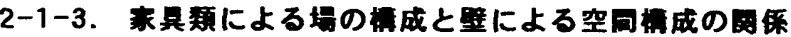

家具類による場は、その構成の正確さから三つに分類できる。まず第 一は初期段階、第二は华完成段階、第三は室構成に統合された段階であ る (表2)。初期段階ではつの道具の組み合わせ程度しか見られない。 また壁は主に衙立的にしか圈かれていない。場の発生の段階に相当す る。準完成段階では主として不完全囲いとともに、複数の家具や人形群 によって、場がほぼ正しく構成される。中には意味不明の家具類構成も ある。用いと場の共存の段階の前半に相当する。これは壁による完全な 囲いがまだできていない段階である。この段階の中間のIr1 以降、外庭 の場が明摬になる。空構成に統合された段階では、家具類構成は完全に 壁による室構成と融合しており、家具類による不明確な權成はどこにも なくなる。この段階では、Ym(26)のように不完全囲いのものもあるが、 殆どの事例で完全な囲いができるようになる。以上のように家具類によ る場の構成と、壁による空間構成は完全に対応しており、決して壁杽成 だけか、孤立して行われているわけではない。

また家具類による場を道具別に見ていくと、構造化されているか石 加に関わらず、机、椅子、トイレ、遊具の使用頻度が非常に高い。さ らに門と玄関もよく使われる。また建物と外庭の区別は、ほぼ囲いと 場の共存の段階以降に可能であるが、外庭の樹、芝生、花などはそれ よりも早く、場の発生の段階から使われる。これらの特徽には、園児 達の日常生活における行動の文脈が感じられる。

\section{2-2. 人形による空间棈成}

知的障害児の害駼 3) では、人形を配置した作品は 55 例中 30 例 (54.5\%)、自分人形を配置したのは 17 例(30.9\%)であった。今回は、40 例中36例(90\%)とほとんどの園児が人形を配娄し、自分人形を配置し たものも 34 例(85\%) と知的障害児に比べて多かった。

配固した人形の総数を男女別、作品の段階別に表 3 に示す。平均値 を見ると男児より女児の方が、人形を圧倒的に多く使う頓向があるこ
とがわかる。

原初的段膡の作品は、 ボード上に構造化された意 味のある場を持たないため に、非常に人形が少ないも のとなる。 $\mathrm{He}(1) 、 \mathrm{Ik}(4) 、$ $\mathrm{Mk} 3(6) 、 \mathrm{Mm} 1(7)$ は人形を 一つも貫くことができない。 箱庭療法や世界テストにお いても人物の不在は見られ、 それはエネルギーのそしさ や自我の未熟さ、空虚性の

\begin{tabular}{|c|c|c|c|}
\hline 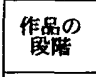 & 䍊内馀者 & 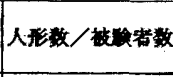 & 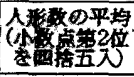 \\
\hline \multirow{3}{*}{ 泉初的 } & 男児 & $2 / 4$ & 0.5 \\
\hline & 女児 & $8 / 5$ & 1.6 \\
\hline & 全体 & $10 / 9$ & 1.1 \\
\hline \multirow{3}{*}{ 场の発生 } & 男児 & $47 / 3$ & 15.7 \\
\hline & 女児 & $105 / 5$ & 21.0 \\
\hline & 全体 & $152 / 8$ & 19.0 \\
\hline \multirow{3}{*}{$\begin{array}{l}\text { 用い之拱 } \\
\text { の共存 }\end{array}$} & 男呪 & $35 / 5$ & 7.0 \\
\hline & 女昌 & $175 / 14$ & 12.5 \\
\hline & 全体 & $210 / 19$ & 11.1 \\
\hline \multirow{3}{*}{ 鏊体占る } & 男児 & $29 / 2$ & 14.5 \\
\hline & 女児 & $49 / 2$ & 24.5 \\
\hline & 全体 & $78 / 4$ & 19.5 \\
\hline \multirow{3}{*}{ 合計 } & 男児 & $113 / 14$ & 8.1 \\
\hline & 女昌 & $337 / 26$ & 13.0 \\
\hline & 全体 & $450 / 40$ & 11.3 \\
\hline
\end{tabular}

あらわれとされる4,10)。人形が見られる作品では、正面を向く[Ua(2)、 $\mathrm{Mk}$ 2(5)、Mm2(8)]、自分人形を粗くことができない[Ua(2)、Dm(9)]、 自分人形のみをなんとか道具と結びつけることができる[Mk1(3)、 $\mathrm{Mk} 2(5)] 、$ 列状になる[Mm2(8)、Dm(9)]といった特徵が挙げられる。

場の発生の段階以降、人形数は非常に増え、自分人形も必す圈かれる ようになる。しかし、構造化された意味のある濹を持たない空間構成が 存在する作品では、Uk1(11)やMm3(15)のように正面向きの列状配置に なるものもある。構造化された意味のある埸に人形が暟かれると、それ は場の意味に応じた向きに配置される対象中心的な構成となる。

ところで、壁を抽象的に使用し始める、囲いと場の共存の段階では、 配置される人形数が少なくなるという面白い現象が見られる。壁によ る全体統括の段階になると、再び人形が多く置かれるようになる。

人形による空間笨成のテーマは、わかりにくいものも多いが、犬小 屋や花を垷める、遊具で遊ぶ、ブランコやすべり台やトイレの順番待 ちをする、お昼寝する、教室や外庭で輸になって遊ぶなど様々なもの がある。人形は特に遊具と結びつきやすい。そうでない子も何人かい たが、その中には女児が多いという㑯向がある。また母親と一緒の登 下園を示すために、人形が群をなして門と結びつくものもよく見られ る。原初的段階の作品で、人形を置くときに河らかのテーマがある と推测されるものもある。

制作そのものが物語をともなった人形遊びの例もある。Te1(19)は、 人形に「わたし」「おとうさん」などの役割を与光、口真似をしながら 制作と同時に人形遊びを行う。Ih2(38)も制作と同時に人形を移峌さ せ、園での生活の様子を時間の経過に沿って以下のように示す。はじ めに門の外に母親を置いて登園時の様子を示す。つぎに自分が部塬で KK法をしている場面や圈児が並んで歌っている場面を作る。やがて 園児全部を庭に出し、斗親が迎えに来るまで庭で遊んでいる場面を作 る。それから園児と母親を榐の外に出し、帰宅風景を示す。さらに保 㕕室の中にベッドを前べ、それぞれの上に園児を寝かせて「お泊まり 保育」の様子を示す。

このように家具類と同様、人形にも園児達の日常生活における行動 の文脈が感じられる。

\section{2-3. 同一被卧者の推移}

表 4 に、実絤を 2 回以上行った被験者の推移を示す。寒験と赛験の 最大時間間隔は、 Ir1(21)から Ir2(34)の 1 年 5 ヶ月である。2 回目、3 回目の作品が前回よりも下位の段階となるものは見られず、それらは 前回と同じ段階にとどまるか、もしくは上位の段階へと移行する。そ こでは、例えば原初的段階からいきなり壁による全体統括の段階に飛 


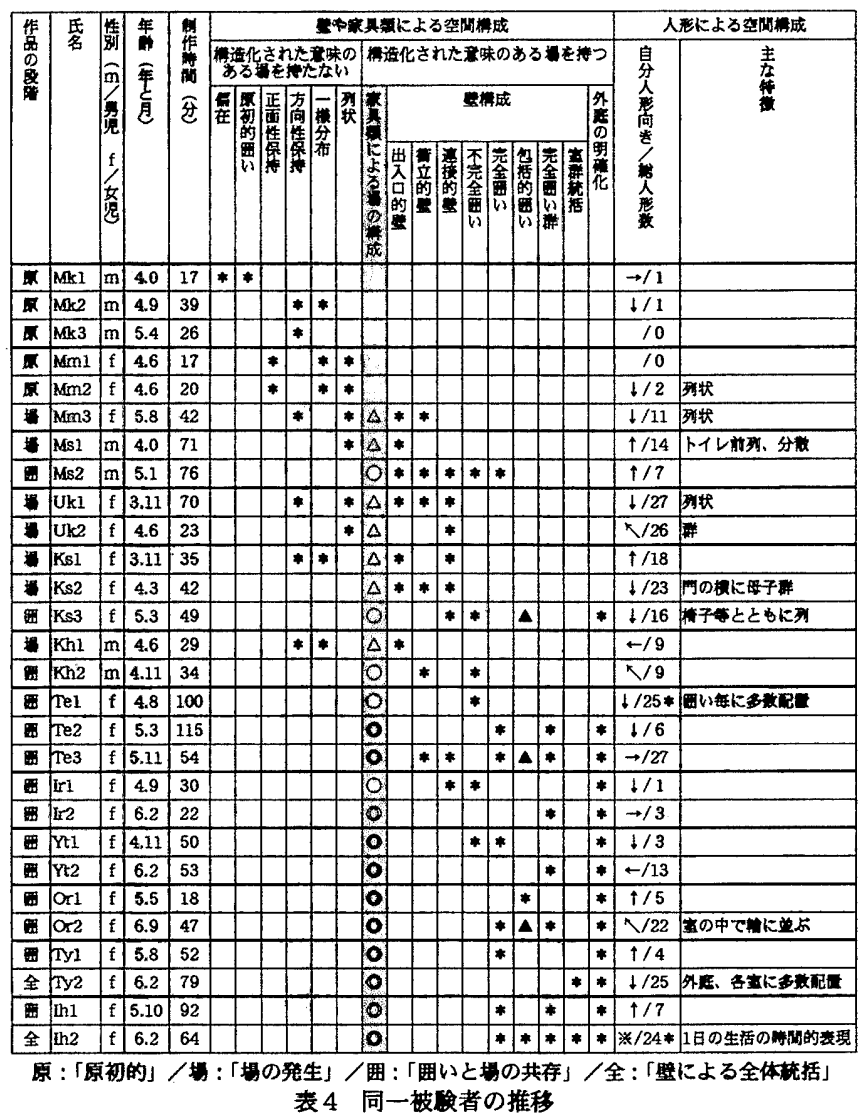

羅するというようなことはなく、順を追った段階の移行が確認でき る。ただし同一被験者の実験回数はまだ少なく、今後事例を増やす。 2-4. 因式

$\mathrm{KK}$ 法では箱庭とは異なり、1/50のスケールに統一された道具、モ デュール化された抽象的形㸃の壁などを使う。これによって、壁の組合 せによる幾何学的形態や家具類の機能的組合せ等が空間構成の上に現れ る。その背後に、表象不可能だがそれらを成り立たせている内的枠組み が存在すると仮定する。これが図式の構造的側面である(もちろん人形 にもこの側面が見られる)。今回の園児の実珨では発達という意味にお いて、分裂病者などと異なり、構造的側面が強く空間構成に出てくる㑯 向がある。KK法では、課題を与えてそれに答えるという従来の実蜕的 方法とは異なり、生活空間を制作する行為の中で、日常生活に密著した 文脈の中から、生きた状態で図式の構造的側面が出てくる。

またKK法は、家具や人形といった具象的なミニチュア模型も多く使 う。そのため園児の個人的内面の心理、例えば、家庭噮境や身近な生活 での曾藤、成長過程における自己実現のための曾藤などが、空間構成か ら読みとれる。これは箱庭で言う心像にあたり、図式の内容的側面と言 える。ただしこの側面も、構造的側面を基盤として初めて成立する。し かし我々は、実験に毎回同席して下さる園の先生の協力を得ているが、 個々の團児の内容的側面を、臨床心理学のように長期間にわたり、哚く 考察することができないため、十分な成果を得られない。

このように両側面が同時に空間構成に現れるのはKK法の特徽であ る。両側面の関保は、対立するものではなく、生活空間の内的基準を 相異なる二面から現す両義的なものであると考える。両者は中井 ${ }^{11)}$ の構成的空間之投影的空間に類するものである。

\section{2-4-1. 因式の梅造的㮩面}

図式の構造的側面には、構造化された意味のある場を持たないもの
と持つものという、大きく分けて二つが存在することが空間構成からわ かる。後者は、成人にも十分理解できるものである。我々は特に年少の 園児によく見られる、前者の図式に注目する。衛籍が風貫構成法で、各 アイテム間の有機的結合がない作品を「世界図式の不成立」9)報告 するように、一般には、構造化されていないものに対しては図式がな いと吾われる。しかし構造化されていない中にも、KK法では似たよ うな傾向にある作品が幾つも見られるのである。従って現時点では、 それらの背後にあるものを「図式」と呼ぶことにする。この図式に基 づく機珹的で均買、そして幾何学的な空間構成が、現代建築や伝統的な 宗教建築などの空間と類似することも多い。

以下、園児の作品から読みとることができる図式の詳細を報告す る。ただし箱庭療法の作品の蛇が、再生の図式であるというような関 係は、今回の、図式の構造的側面と空間構成の間にはない。そのため 空間構成に用いた用語をそのまま図式に用いることになる。

1）構造化された意味のある場を持たない図式には、以下のものが あることが判明した。道具の分布に関する図式として而在と一權分 布がある。偏在はボード全体への構想力に乏しく、偏った小さな筙囲 にしか配置することができないものである。また He(1)やUa(2)の作 品はボードの左手前䧉に小さく固まったまま終わったが、そこから作 品がボード全域に広がっていく例も多い。Uk1(11)など 40 例中 8 例 が、制作初期に注左手前隅のみを使うが次第に右側へと拡大してい き、まさに左手前隅が誕生の地であった。箱庭療法の作品においても 左手前隅に小さく存在していた世界が、治療が進むにつれて全域に拡 がっていく例は多いという。偏在は「新しい可能性が開発されていく 源泉」山の図式とも考えられる。一様分布は、ボード全体に道具がほ ぼ均等に配置され、中心や囲われた場のないものである。ここでは道 具間関保への意識がないが、しかしボード全体にまんへんんなく置くと いう義務感はあり、これに基づく図式である。道具の向きに関する図 式として正面性保持、ボードの枠の方向性保持、そして向きの意識 のないものがある。正面性保持は自己中心的な見方によるもので、そ れは対象中心的な見方ができないということを示している。しかし園 览が自分に対面させて道具を置くという原初的な空間構成には、道具 に対する彼らの強烈な思い入れが感じられる。子どもの描画において も、人や家などが正面向きに、しかもそれらが誇張して描かれるとい うことがよく見られる。従って正面性保持の図式は非常に感情的な側 面を持つと言える。これは正面性の強い建築や崕刻、さらには正面性 がデフォルメされた絵画などと共通の現象である。方向性保持につい

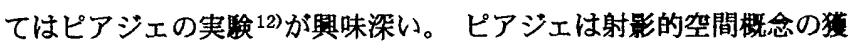
得を調べるために、矩形のテーブル上に、多数のポールで、テーブル の隣接する二辺それぞれの上の二つのポールを斜めに結ぶ直線を構成 させる実験を行う。そこで、はじめに実験者が置いた二本のポールの 間にねらいをすまして、他視点を基準とした直線を楧成することがで きない子どもは、矩形のテーブルの端の形にひきずられて、テーブル の二辺に平行な直線を二本つくるにすぎないという例を報告する。方 向性保持も同じように、背景にあるボードの形の知觉的な効果にのみ 左右されたものではなかろうか。さらに原初的目いの図式がある。园 うことは庇護された住まいの原型である。囲いの形にはより原初的な 円とそれに䌇く四角がある。前者はあらゆるものを示す描画の円に相 当する。さらに列状の図式もある。列状は、同種のものの組み合わせ はできるが、異種の道具や異種の構造を組み合わせることができない 
ことに起因するものと考えられる。これまでにも分裂病者 ${ }^{1}$ や知的障 害児3のKK法で、家具や壁や人形による多くの列状が見られ、河合4 が非統合的な箱庭作品の特徽として挙げる機械的配置や画一性、木村

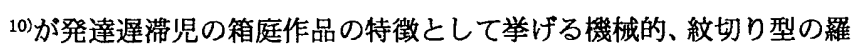
列との類似が指摘される。これは、多様な表現や新たな表現を試みる エネルギーの不足による省エネ的な配置であるという意見もあるが、 しかしUk1(11)は省エネ的というには程遠いほど熱心に、楽しそうに 列状を構成する。実際の生活空間でも鳥居や灯篭の列、歴史的建造物 や現代建築における回廊の列柱等に多くの例があり、それらは列状に よって積極的にその場の雲囲気を高めている。

2）構造化された意味のある場を持つ図式には以下のものがある。ま ず、壁を使わず家具颣のみで場を檽成する图式がある。それととも に、壁を墅立や出入口として家具類と粗み合わせて場を满成する 図式がある。これらの図式に基づいて、作品では場が発生する。ここで は壁は、まだ抽象的に扱われておらず、場を構成する全ての道具は、自 分の生活と深く関わる具体物として捉えられる。このような中で連接的 壁は非常に興味深いものである。それは列状の図式に基づくものとも考 えられ、また衝立として家具類と組み合わせて場を構成する図式に基つ くものとも考えられる。さらには後に出てくる囲いの図式の萌芽とも見 ることができる。壁を連接するということはこのように幾つかの図式を 結びつける役割を持つのかもしれない。その後、家具類による場ととも に壁でL字型やコの字型の不完全困いを檽成する图式がでてくる。 この形式で広い範囲の複雑な空間まで構成されるものもある。さらに家 具類による場とともに完全国いや完全国い群を楣成する図式がある。 全体を包括的に国う図式もある。このような様々な壁の囲いは抽象的 な空間の図式の萌芽と孝えられる。やがてそれらの構造化が進むと、室 や鹿下や玄网によって全体を椣成する図式がでてくる。

また、机や椅子、トイレ、門、遊具等による構成、そしてそれらに 密着して配置された人形群などのそれぞれに対して、国児の日常生 活に固有な諸行野の图式があることがわかる。

\section{2-4-2. 図式の内容的㽢面}

図式の内容的側面では、Mk1(3)のように岐しい家庭懪境が作る図 式が、䇴を㠜めるような原初的囲いを構成するもの、Ik(4)のように秒 利によって与えられた崩俵感の図式が作品を破壊してしまったもの、 また Mm1(7)のようにお洞らしによる緊張感からくる図式が、列状 配置を作る例などが観察された。これらの例はいずれも原初的段階の ものである。それ以降の、場が構造化したときの内容的側面について は、いまだ顕著な特徵が発見されていない。

\section{䎯㶾}

1）一つの作品には幾つかの特徽的な空間構成が互いに重なり合って いる。壁や家具類による空間構成には、大きく分けて、構造化された 意味のある場を持たないものと持つものという二つがある。前者には 偏在、原初的囲い、正面性保持、方向性保持、一様分布、列状がある。 後者には家具類による場の構成、出入口的壁、衝立的壁、連接的壁、 不完全囲い、完全囲い、包括的囲い、完全囲い群、室群統括がある。 2)各作品と各空間構成を大まかな発達の順に並べて対応させることに より、作品群は原初的、場の発生、囲いと場の共存、壁による全体統 括の四つの段階に大別することができる。

3）幼稚園児は知的障害児より人形を多く使うことが判明した。また男
児より女児の方が、人形を圧倒的に多く使う傾向があることが判明した。 原初的段階の作品は、ボード上に構造化された意味のある場を持た ないために、非常に人形が少ないものとなる。場の発生の段階以降、 人形数は増加し、自分人形も必ず置かれるようになる。ただし囲いと 場の共存の段階では、配置される人形数が少なくなるという面白い現 象が見られる。壁による全体統括の段階になると再び人形が多く置か れるようになる。

また、制作そのものが物語をともなった人形遊びの例もある。人形 や家具類には、園児達の日常生活における行動の文脈が感じられる。 4）同一被験者の実験においては、2回目、3回目の作品が前回よりも 下位の段階となるものは見られず、それらは前回と同じ段階にとどま るか、もしくは順を追って上位の段階へと移行する。ただし同一被験 者の実験回数はまだ少なく、今後事例を増やす。

5）KK 法の空間構成から、園児らの心の中にあると想定される偏在、 一様分布、正面性保持、方向性保持、原初的囲い、列状、家具類のみ で場を構成する図式、壁を衝立や出入口として家具類と組み合わせて 場を構成する図式、不完全囲いを構成する図式、完全囲いや完全囲い 群を構成する図式、全体を包括的に囲う図式、室や廊下や玄関によっ て全体を構成する図式などという、いくつかの図式の構造的側面を抽 出した。また図式の内容的側面の考察は十分ではなかったが、厳しい 家庭環境、砂利による崩壊感、お漏らしによる緊張などがもたらす図 式と空間構成との関わりが興味深かった。

注

1)ピアジェの schème とは、「ひっかく」「かむ」などの行為に関する要素 的活動単位である13)。これに对して我々の図式 schema とは、活動単位の協応 によって空間認識に関わる、より全体的体制についてのものである。

2)福島は、芸術と狂気との関係における重要な概念の一つとして、クリスの「創 造的退行」をあけ、それは「意裁的=概念的=論理的な心理過程から、より原 初的 $=$ 根源的=生命的な心理過程」が優先する世界だと述べる ${ }^{14}$ 。この意味で ここでは「根源的な図式」としている。

3)スクリブルはなぐり描きとも言われる。「スクリブルは次第に単線として輪

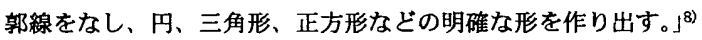

4)子どもが最初に描く閉じ围まれた形は円である。アルンハイムはこの円のこ とを「本源的円 The Primordial Circle」と名付け、次のように述べる。「形が分 化するまでは、円はまるさをあらわすのではない。それは特にどの形をあらわ すのでもない代わり、どんな形でもあらわすのである。」15)

\section{考文献}

1）岡崎甚幸,伊藤達彦: 居住空間構成法と分裂病者, 日本建築学会計画系論文 報告集 第 436 号,pp.196-208,1992 年 6 月

2）岡崎甚幸: 居住空間構成法と児童, 日本建築学会計画系論文報告集 第438 号,pp.109-118,1992 年 8 月

3）岡崎甚幸,大井史江,山口直子,浦崎寿輝 : 居住空間構成法と知的障害児, 日本 建筑学会計画系論文報告集 第 496 号,pp.237-245,1997 年 6 月

4）河合隼雄 : 箱庭療法入門,誠信書房, $1969: 11,17,34,36-37$

5）河合隼雄 : ユング心理学入門,培風館, 1967:114

6) Piaget,J. \& Inhelder, B., 僮沢武久訳 : 第 2 章 心像, 現代心理学VII 知能と思 考, 白水社, $1972: 102-103$

7) Plaget,J., 波多野完治・滝沢武久訳 : 知能の心理学, みすず書房, $1960: 21$

8）融本夏木他監修: 発達心理学辞典, ミネルウァ書房, $1995: 237-238,372$

9）衛藤進吉 : 急性分裂病者の回復過程における世界図式の変遷, 芸術療法 vol.16,1985: 8-9

10）木村晴子 : 箱庭療法,創元社, $1985: 21,61,79$

11）中井久夫: 中井久夫著作集 第 1 巻 分裂病,岩崎学術出版社, 1984: 47-82

12）波多野完治編：ピアジェの認識心理学, 国土社, 1965:48-50

13）浜田美男 : ピアジェとワロン,ミネルウァ書房,1994:111-116

14）福島章: 天才の精神分析, 新曜社,1978:302-303

15) Arnheim,R., 波多野完治・関計夫訳 : 美術と視賞, 美術出版社,1963: 220,225

（1998年 5 月10日原稿受理，1998年10月22日採用決定） 